University of New Orleans

ScholarWorks@UNO

Department of Economics and Finance Working

Papers, 1991-2006

Department of Economics and Finance

1991

\title{
Deposit insurance, market discipline and off-balance sheet banking risk of large U.S. commercial banks
}

\author{
M. Kabir Hassan \\ University of New Orleans \\ Gordon V. Karels \\ University of Nebraska-Lincoln \\ Manferd O. Peterson \\ University of Nebraska-Lincoln
}

Follow this and additional works at: https://scholarworks.uno.edu/econ_wp

\section{Recommended Citation}

Hassan, M. Kabir; Karels, Gordon V.; and Peterson, Manferd O., "Deposit insurance, market discipline and off-balance sheet banking risk of large U.S. commercial banks" (1991). Department of Economics and Finance Working Papers, 1991-2006. Paper 52.

https://scholarworks.uno.edu/econ_wp/52

This Working Paper is brought to you for free and open access by the Department of Economics and Finance at ScholarWorks@UNO. It has been accepted for inclusion in Department of Economics and Finance Working Papers, 1991-2006 by an authorized administrator of ScholarWorks@UNO. For more information, please contact scholarworks@uno.edu. 


\section{UNIVERSITY OF NEW ORLEANS}
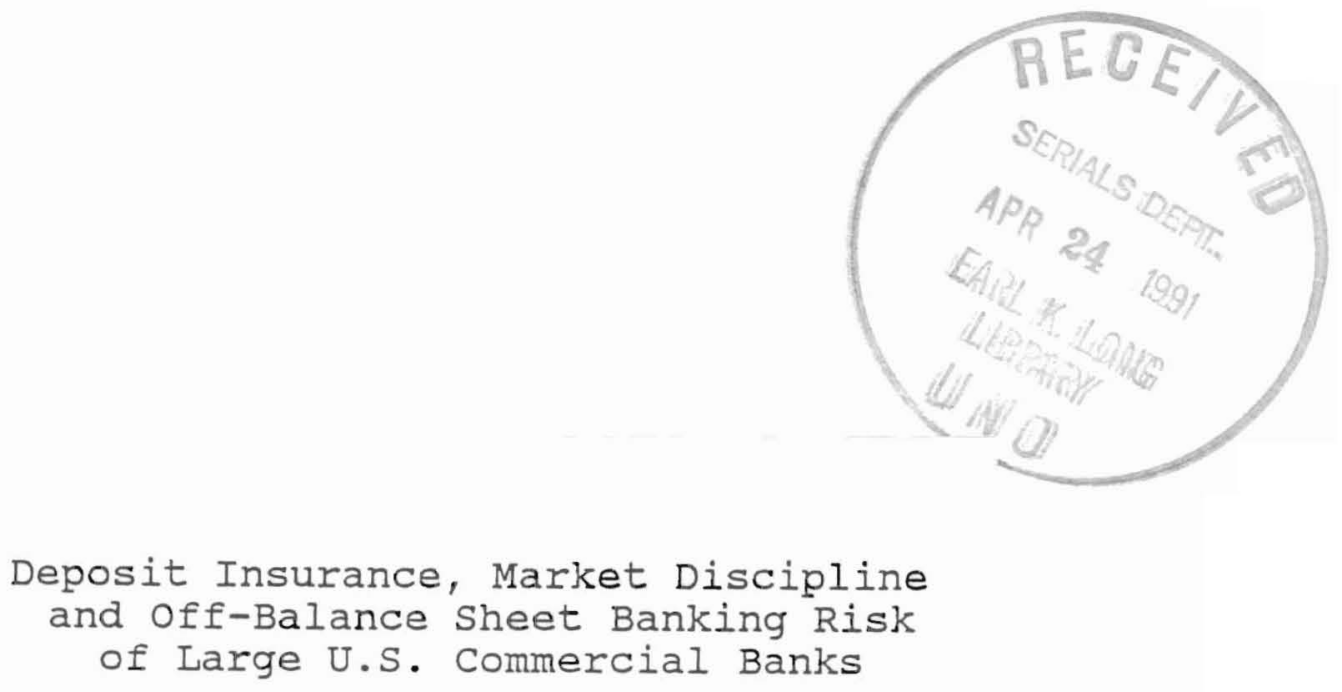

M. Kabir Hassan*

Gordon V. Karels** and

Manferd 0. Peterson***

Working Paper \# 9-91

\section{ECONOMICS AND FINANCE WORKING PAPER SERIES}

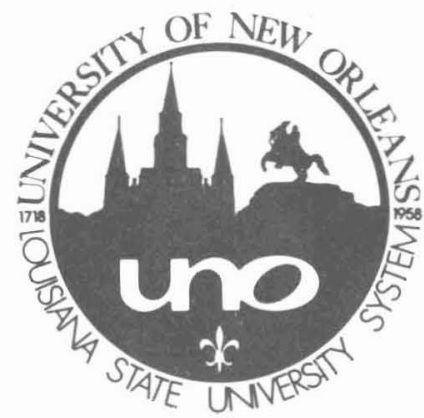

Department of

Economics and Finance University of New Orleans 


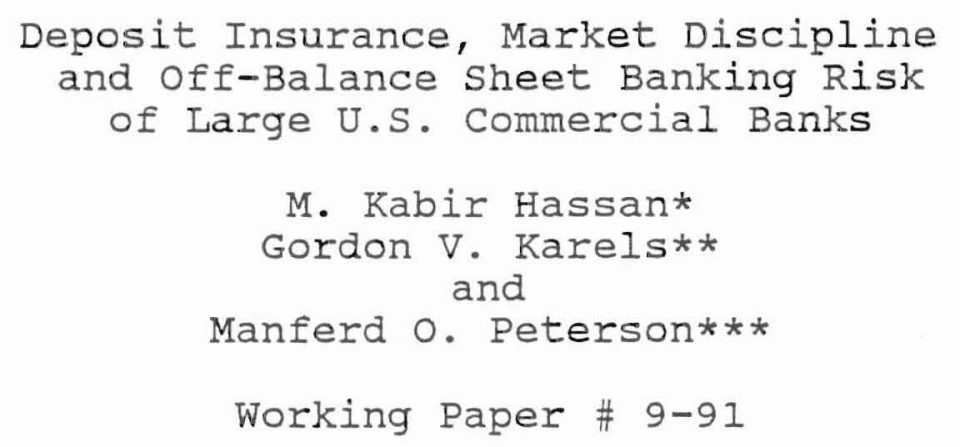

* Assistant Professor of Finance, Department of Economics and Finance, University of New orleans.

** Associate Professor of Finance and ***Marshall Professor of Banking, Department of Finance, University of Nebraska-Lincoln.

For additional copies of this working paper or a current list of the papers available in this series, please contact:

$$
\begin{gathered}
\text { Professor Nicholas Mercuro } \\
\text { Working Paper Series } \\
\text { Department of Economics and Finance } \\
\text { University of New Orleans } \\
\text { New orleans, LA } 70148 \\
\text { phone:(504) 286-6270 }
\end{gathered}
$$

Not for quotation or attribution without permission of authors.

$$
\begin{aligned}
& \text { All rights reserved. } \\
& \text { COPYRIGHT @ } 1991
\end{aligned}
$$




\section{DEPOSIT INSURANCE, HARKET DISCIPLINE AND OFF-BALANCE SHEET}

BANKING RISK OF LARGE U.S. COMERCIAL BANKS

\section{ABSTRACT}

The "market discipline" of off-balance sheet banking activities (OBSA) has been reexamined by employing contingent claims valuation techniques to derive implied asset variances from bank equity and deposit insurance, and from risk-premia for bank subordinated debt. Specifically implied asset variances have been calculated from contingent valuation models and have been regressed over on-balance accounting risk variables and off-balance sheet activities. These implied asset variances are better than equity variance or risk-premia in proxying total risk because they consider both the non-linear nature of contingent claims model and the impact of closure rules. Empirical results document the existence of "market discipline" of some OBSA. Harket participants price these 0BSA as risk-reducing. Therefore, regulatory additional capital requirements of such OBS may be inappropriate. 


\section{Introduction}

This paper examines "market discipline" of off-balance sheet activities (OBSA) by employing option-pricing models to calculate bank asset risk. OBSA have been growing rapidly in recent years. Total OBSA grew from 1.4 billion dollars in 1984 to 5.7 billion dollars in 1988. Such OBS.A represented 58\% of total bank assets in 1984 and grew to $176 \%$ of total bank assets in 1988 (Table 1). As the volume of OBSA increased, bank regulators are concerned that such OBSA would increase riskiness of banls. The risk-based capital requirements of OBSA explicitly assume that Standby Letters of Credit (SLCs) are as risky as loans, Commercial Letters of Credit (CLCs) are as risky as municipal security investments, and Loan Commitments are as risky as the sale of federal funds. Whether or not such assumptions are warranted remains an open question. Given the growing role of OBSA and the attendant problem for bank regulators, it is important to analyze empirically the riskiness of OBSA.

Off-balance sheet banking refers to banking products and practices not related to traditional forms of portfolio lending. Such OBSA involve earning fee incomes by means of transactions that are not registered on bank's balance sheets. As a result of its OBSA, a bank faces three general types of portfolio risk: credit risk on underwritten guarantees, interest rate risk due to asset and liability mismatches on commitment takedowns and interest rate swaps, and liquidity risk due to the over-extension of obligations.

Banks are required to report OBSA to the FDIC beginning 1984. Due to data availability problems, the literature on off-balance sheet activities and their risk has primarily been theoretical.

A key rationale for OBS banking capital regulation is an assumed information asymmetry between bank managers and liability holders. The 
regulatory presumption is that such OBS activities are risky and the market fails to recognize the risk embodied in such OBS activities. The "market discipline" studies of OBS banking risk have addresed the question of whether market prices of bank liabilities reflect the risk of OBS activities. If "market discipline" exists and off-balance sheet activities are found to be risk-sensitive, bank liability holders can distinguish OBS banking risk. The assumed information asymmetry rationale for capital regulation of OBS activities, therefore, becomes less convincing.

The standard approach used to determine if market prices of uninsured liabilities reflect the risk of OBS activities is to regress the relative costs of bank funds against on-balance and off-balance measures of risk. This approach is inadequate because uninsured bank liabilities or equities are subordinated claims whose costs are not linear or monotonic functions of bank risk. Horeover, this approach fails to account for the fact that banks are regulated. The fact that regulators may apply solvency rules in ways different from investors complicates the valuation of subordinated claims.

The purpose of this paper is to reexamine the impact of "market discipline" on OBS risk by modeling closure rules explicitly and using contingent claims pricing to compute the implied variance of bank assets. This paper calculates bank asset risks two ways and regresses these market-determined asset risks over on-balance and off-balance activities. First, this research calculates implied bank asset variance given the contingent claims nature of equity and deposit insurance (Ronn-Verma, 1986). Second, this paper calculates implied asset variance given default-risk premia and subordinated debt option pricing model (Gorton and Santomero, 1988). Once implied asset variances are calculated, these asset risks will be regressed over on-balance accounting measures of risk 
in addition to OBSA to exanine "market discipline" of such OBSA. The underlying premise of this study is that bank equity-holders and subordinated debt-holders are more exposed to OBS risk than deposit-holders. Therefore, their assessment of the rishiness of OBS activities is realistically determined.

II. Previous Research and Importance of this Study

The empirical evidence of the "market discipline" of OBS banking activities is inconclusive. Lynge and Lee (1987) found that the coefficients of independent variables incorporating OBS banking activities are significantly negative in a model explaining total risk, but insignificant in a model explaining systematic risk. Brewer, Koppenhaver and Wilson (1986) found that SLCs reduce systematic risk but loan commitments and commercial letters of credit do not affect systematic risk. Pavel (1987) found that loan sales have little impact on bank risk. dvery and Berger (1988) regressed three bank performance measures against OBS activities and found that SLCs are associated with poor bank performance but loan commitments are associated with better bank performance.

Pettway (1976, 1976a) investigated the accounting factors affecting the risk-premium of a bank's capital notes and found that dividend yield and earnings growth rate are significant explanatory variables. Cramer and Rogowski (1985) investigated the relationship between deposit costs and bank-specific risk measures, but failed to find any significant relationships. Baer and Brever (1985) regressed CD rates over various accounting risk measures and found that these rates are positively related to risk measures over the period 1979-82. Hannan and Hanweck (1988) employed survey data on CD rates for five different maturities and found that variability of earnings and bank capital are significant determinants of CD risk-premia. 
Goldberg and Lloyd-Davies (1985) explained CD rates as a function of the general level of interest rates and various measures of bank risk including standby letters of credit. They found that $C D$ rates rose with increasing leverage from increases in SLCs but fell with increases in SLCs as a proportion of total risky assets. Since these two factors tend to cancel each other, the net effect on bank risk of an increase in bank's SLC exposure is negligible.

In a paper by Avery, Belton and Goldberg (1988) a cross-sectioon study of subordinated debt pricing was conducted for both 1983 and 1984. Examining the spread over the comparable Treasury yields these authors were unable to demonstrate the effect of any balance sheet or income statement data on bank costs. Recently, Gorton and Santomero (1989) used a contingent pricing model and regulatory closure rule to examine the relationship between bank risk and accounting risk factors. They found credit and interest risk variables are significant in models in which bank debt is aassumed either homogeneous or heterogeneous (junior vs. senior) with one year maturity. They attribute this finding to the methodological improvement of their research over previous studies. They argue that (i) the nonlinearity of contingent claims pricing may not be captured by linear regression; (ii) bank subordinated debt may sometimes behave like equity; and (iii) the effects of regulatory closure rules, while difficult to capture, are not modeled at all in previous literature. Although Avery, Belton and Goldberg (1988) and Gorton and Santomero (1989) studies do not include OBS items as explanatory vaariables, these two studies show the appropriateness of default-rish premia and implied asset variances methodologies in examining the "market discipline" of OBS banking risk.

The empirical literature of OBS banking risk contains a number of limitations, which this research seeks to rectify. By measuring OBS banking 
risk in a more theoretically appealing way, bank regulators and investors can gain a better understanding of the size of the risks that are involved and policies that might make effective control possible.

This research reports on two capital market tests of OBS banking risk: the impact of OBS activities on the implied asset variances calculated from bank equity and deposit insurance and implied asset variances calculated from subordinated debt risk-premia. This research improves upon the existing empirical literature in the following ways.

First, this paper contends that equity risk is an inappropriate proxy for total risk for regulated banking industry because both stockholders and regulatory agencies bear banking risks when such institutions fail. Regulatory agencies bear part of OBS risk because bank depositors are protected by de facto deposit insurance. Given the contingent claims nature of equity and deposit insurance, implied asset variances are calculated.

Second, the empirical literature, to date, has ignored the impact of OBS risk on the dafault-risk premia borne by the subordinated debtholders. This study uses contingent claims pricing of subordinated debt to calculate implied variance. These procedures are superior to previous studies because these can assess directly whether OBS banking risk is correlated with market risk while avoiding direct use of the yield spreads which are neither linearly nor monotonically related to bank asset risk. Third, this research investigates the differential impact of various OBS items on bank risk.

III. Bank Asset Risk in Option-Pricing Frameworks

3.1 The Valuation of Bank Asset Risk Under Flat Deposit Insurance Premium The first measure of asset risk used in this research is the rish-based deposit insurance premium estimated by Ronn and Verma (1986). Ronn and Verma 
demonstrate that empirical estimation of risk and deposit insurance premium is tractable when time-series data on the market's value of bank's equity and the book value of its debt are available. Market perceptions of the FDIC bailout policy are explicitly modeled so as to eliminate the bias in inplied values of assets and their volatilities.

Ronn and Verma applies Black-Scholes (1973) option pricing model to calculate a 'fair' per dollar deposit insurance premium that takes into consideration the FDIC's bailout policy. Ronn and Verma (1986) start with the following notation:

$\mathrm{V}=$ the unobserved post-insurance value of the bank's assets;

$B=$ face value of total debt liabilities;

$\sigma_{\mathrm{v}}=$ the instantaneous standard deviation of the rate of return on the value of the bank's assets;

$T$ = time until next audit of bank's assets;

$\delta=$ dividend per dollar of value of the assets, paid $\mathrm{n}$ times per period. Under the assumption of a constant variance for the rate of return on the bank's assets, Merton's (1977) insurance premium per dollar of deposits, d, is given by

$$
\mathrm{d}=\mathrm{N}\left[\mathrm{Y}+\sigma_{\mathrm{v}} \sqrt{\mathrm{T}}\right]-(1-\delta)^{\mathrm{n}}(\mathrm{V} / \mathrm{B}) \mathrm{N}(\mathrm{Y})
$$

where

$$
\mathrm{Y}=\left[\ln \left\{\mathrm{B} / \mathrm{V}(1-\delta)^{\mathrm{n}}\right\}-\sigma_{\mathrm{v}}{ }^{2} \mathrm{~T} / 2\right] / \sigma_{\mathrm{V}} \sqrt{\mathrm{T}}
$$

$N(\cdot)$ is the cumulative density of a standard normal random variable; $\sigma_{\mathrm{v}}$ is the standard deviation of the rate of return on $\mathrm{BHC}^{\prime}$ s assets; $\mathrm{T}$ is the time to expiration, i.e., the time until the next audit of the BHC. (assumed to be 1); $V$ is the value of the BHC's assets adjusted for stock-splits and dividends; $B$ is the value of the BHC's debt. 
Two variables in the above equation are not empirically observable: $Y$ and $\sigma_{\mathrm{v}}$. They can, however, be solved for by representing the equity of a bank holding company as a call option on the assets of the firm with the same maturity as debt and the striking price equal to the maturity value of the debt (Black and Scholes, 1973).

Ronn and Verma (1986) point out that the FDIC does not liquidate a bank as soon as it observes that its net worth is negative. Rather the FDIC tries to revive the bank. The FDIC is concerned about containing the disruptive effect of an individual bank failure to ensure that it never reaches the magnitude of a bank run. These concerns not only have the effect of allowing a bank to operate up to a certain point beyond complete erosion of net worth, but also are perceived by the market to have such an effect. They assume, hovever, that some hypothetical limit of erosion of value exists such that revival becomes too costly. This hypothetical limit can be expressed as a percentage of total debt of the bank. This also alters the boundary condition to be applied to the equity, construed as a call option. The closure rule is therefore modeled as follows: the FDIC liquidates a bank if $\mathrm{V}_{\mathrm{T}}<\rho \mathrm{B}$ where $\mathrm{V}_{\mathrm{T}}$ is the terminal value of assets at time $\mathrm{T}$ and $\rho<=1$ is a policy parameter. Given this modified closure rule and the standard options-theoretic relationship between the instantaneous variances of the derivative and underlying assets, the equity of the bank holding company can be written as:

$$
\mathrm{E}=\mathrm{V} \mathrm{N}(\mathrm{x})-\rho \mathrm{BN}\left(\mathrm{x}-\sigma_{\mathrm{V}} \sqrt{\mathrm{T}}\right)
$$

where $x=\frac{\left[1 \mathrm{~N}(\mathrm{~V} / \rho \mathrm{B})+\sigma_{\mathrm{v}}{ }^{2} \mathrm{~T} / 2\right]}{\sigma_{\mathrm{V}} \sqrt{\mathrm{T}}}$

$$
\sigma_{\mathrm{V}}=\sigma_{\mathrm{E}} \frac{\mathrm{E}}{\mathrm{VN}(\mathrm{x})}
$$


where $E$ is the market price of equity and $\sigma_{E}$ is the instantaneous standard deviation of the return on $E$. Here equity is a fully dividend-protected call because being the recipient of dividends, equity is in fact dividend-protected.

Equations (2) and (3) can be solved simultaneously for the two unknowns, $V$ and $\sigma_{\mathrm{V}}$, for each observed $\mathrm{E}$ and $\sigma_{\mathrm{E}}$. Ronn and Verma show that a $\rho$ of .97 yields an aggregate deposit premium weighted average of about $1 / 12$ percent, the flat rate premium over the data period in this study.

The maturity of debt $(\mathrm{T})$ is assumed to be one year in empirical calculation of models (2) and (3). The equity value refers to the maturity of debt while the deposit insurance refers to periodicity of audit by the insurer. In a regulatory environment, the rational investor would link the debt maturity to audit periodicity. These two maturities cannot be separated in the context of banks because insured deposits account for a large part of the bank's debt and ner deposits made with a bank before the expiration of the insurance are automatically covered by the insurance. At audit time, if the FDIC decides to dissolve the bank, all depositors are paid off. It is therefore reasonable to argue that the time until next audit should be the proper value of maturity (assumed to be 1) in both equations (2) and (3).

The implied variance of bank assets captures the riskiness of a bank and is the underlying driving variable in this study. Ronn and Verma (1986) pricing equations can be extended in the context of OBS banking activities by including OBS items into total debt because not all risks assumed by a bank appear on its book. The implied variances will be regressed over bank on-balance and off-balance sheet activities to test for their risk-taking potential. 
3.2 The Valuation of Asset Risk Under Default-risk Premia

The second measure of asset risk used in this study is in the spirit of Gorton and Santomero (1989). Asset variances of banks are estimated by inverting an option pricing model of default risk-premia of subordinated debt. This approach to risk calculation considers the fact that subordinated debt sometimes behaves like equity and sometimes behaves like debt. This contingent claims pricing model of subordinated debt also considers the nonlinear relationship between market measures of risk and on and off-balance measures of risk. Horeover, subordinated debt pricing considers the fact that banks are regulated.

The contingent claims valuation model, derived by Black and Scholes (1973), was applied by Merton (1974) to liability pricing in the case of a single issue of nonconvertible debt. In reality, capital structures involve equity and multiple issues of callable non-convertible sinking fund coupon debt of different maturities and possibly different pricing mechanisms. The contingent claims valuation theory is not rich enough to capture many aspects of real world securities. Nonetheless, empirical tests in this research are based upon contingent claims pricing of subordinated debt as developed by llerton (1974).

If a firm finances itself solely with pure discount debt and equity, then Jierton (1974) has shown that the default risk premium on the firm's debt, expressed as the spread between the yield on the risky debt $(R)$ and the yield on riskless debt $\left(R_{f}\right)$ of the same maturity is

$$
R-R_{f}=-1 N\left[(V / B) \exp \left(R_{f} T\right) N\left(-d_{1}\right)+N\left(d_{2}\right)\right] / T
$$

where $\mathrm{d}_{1}=\left[1 \mathrm{~N}(\mathrm{~V} / \mathrm{B})+\left(\mathrm{R}_{\mathrm{f}}+\sigma^{2} / 2\right) \mathrm{T}\right] / \sigma \sqrt{\mathrm{T}}$

$$
\mathrm{d}_{2}=\mathrm{d}_{1}-\sigma \sqrt{\mathrm{T}}
$$


where $\sigma^{2}$ is the volatility of the logarithm of assets of bank; $R$ is the yield on subordinated debt and debentures; $R_{f}$ is the yield on Treasuries of the same maturity; $\mathrm{V}$ is the value of the bank's assets; $\mathrm{T}$ is the maturity of subordinated debt (assumed to be 1 ); $B$ is the face value of debt; $N(\cdot)$ is the univariate cumulative normal distribution function. Note that the risk premium, $R-R_{f}$, is a function of leverage $(\mathrm{V} / \mathrm{B})$, time to maturity $(\mathrm{T})$ and asset variance $\left(\sigma^{2}\right)$. In the case of a homogeneous debt issue, the greater the volatility of the firm's assets, the higher the default risk-premium.

Given the default-risk premium and other necessary information, the above pricing formula for subordinated debt is inverted to find the volatility, $\sigma^{2}$, implied by that default-risk premium. Two volatility measures will be calculated. The first volatility measure treats bank debt as homogeneous, imposes a one-year maturity and subordinated debt to assets minus insured debt as the leverage variable. The second volatility measure also treats bank debt as homogeneous, imposes a one-year maturity but uses subordinated debt plus OBS debt to assets minus insured debt as the leverage variable.

Calculations of implied asset variances require the usual assumptions made by Black-Scholes. A maintained assumption of the Black-Scholes option pricing model is that $\sigma^{2}$ is constant and normally distributed. The applicability of contingent claims model in discrete time has been demonstrated by Gorton and Santomero (1989) in their "market discipline" study of bank risk. Horeover, the interest rate is assumed to be nonstochastic. Ronn and Verma (1986) show that relative contribution of interest rate variance to overall variance appears small.

In addition, the following assumptions are used for calculations of implied variances. 
1. Deposit insurance is fairly priced;

2. Aggregation of a bank's multiple issues of subordinated debt by weighted average of yields and maturities is a good approximation.

3. Insured bank debt has the same maturity as subordinated debt.

The assumption that deposit insurance is fairly priced has received empirical support from Pennachi (1987). The fact that some banks have multiple issues of debt with different maturities necessitates the second assumption. The maturity assumption is necessitated by the fact that the banks in the sample have widely varying average maturities of their subordinated debt. Core deposits are perpetual and the remainder debt has an estimated maturity based on turnover measures (Flannery and James, 1984). Although some measure of the maturity of insured deposits is acceptable, there is no standard maturity measure for subordinated debt.

An empirical examination of the bank subordinated debt pricing model is complicated by the fact that banks are regulated by authorities that have broad discretionary powers. The FDIC may keep a troubled bank open or it may liquidate the bank and pay off depositors. The FDIC may also use the purchase and assumption technique of dealing with a troubled bank. An exogenously given closure rule can be adopted about the behavior of regulatory authority. Herton (1978) assumed that banks are audited each year and banks will be closed if, at audit time, its assets to deposit ratio is below one. Ronn and Verma (1986) also assume an annual audit with an exogenously given assets-to-deposits ratio below which the bank is closed. The maturity of debt, used in this study, is effectively one year because banks are audited each year. At examination time, the stockholders have the choice of satisfying the regulatory criteria or forfeiting the bank to the regulators. 
IY. Data and Empirical Results

\subsection{Empirical Hodel}

The following accounting-based risk model is estimated over cross-section and time-series data using the generalized least squares (GLS) technique. The expected signs of partial derivatives appear on each independent variable.

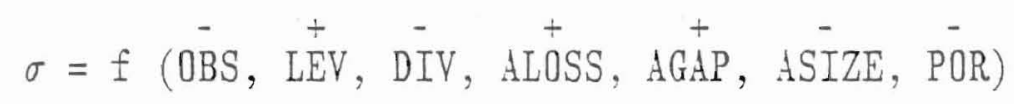

where

$\sigma=$ implied bank asset risk as previously described;

OBS = seven variables constructed from all OBS banking activities included in the RC-L schedule of the FDIC tapes;

LEV = ratio of total liabilities over total assets;

DIV $=$ an index of diversification of the bank's loan portfolio;

ALOSS = ratio of loan loss reserves over total assets;

$A G A P=$ ratio of net position (total market rate assets minus market rate liabilities) to total assets;

ASIZE = logarithm of assets of banks;

$\mathrm{POR}=$ cash dividends over net income.

A pooled cross-section and time-series model, instead of simple 0LS, was employed to perform the econometric analysis for two reasons. Cross-section or time-series data alone ( 32 cross-sections and 5 time-periods) do not yield sufficient degrees of freedom in regression analysis.

Seven off-balance sheet variables are constructed from the 19 off-balance sheet items of the RC-L schedule of bank call and income reports. These variables are AOB, ACOAM, APAPT, ASLC, ACLC, ASTAP and AOBS and scaled down by total assets. Since off-balance sheet items constitute a heterogeneous 
collection of participations; commitments, and other arrangements, it is difficult to represent the influence of these items in any simple way. These independent variables attempt to group items with similar characteristics. Similar off-balance sheet groupings are also done by Lynge and Lee (1988). These variables are reported in Table 2. LEV, DIV, ALOSS, AGAP, ASIZE and POP are proxies for leverage ratio, diversification index, credit risk, interest rate risk, operating risk and dividend payout ratio. These on-balance accounting risk variables have also been extensively used in studies of bank risk literature. Lee and Brerer (1986) used similar variables to investigate commercial bank financial policies and their impact on market determined measures of risk. The authors found leverage, loan-loss, dividend payout, gap variables are significantly related to market measures of risk. Jahankhani and Lynge (1980) also used similar variables in their bank risk study and found similar results. Pettway (19T6) investigated accounting factors affecting total risk and systematic risk, and found that dividend and earnings are significant variables.

Koppenhaver (1987), Pavel (1988), and Pavel and Philis (1987) used a diversification index to examine the diversification potential of SLCs and loan sales. The higher the diversification index is, the higher the diversification potential is in the loan portfolio, and the lower the risk is. This research exploits these previously tested accounting risk-variables in order to examine the "market discipline" of OBSA. All these variables have been deflated by total assets in order to eliminate heteroskedasticity problem in statistical estimation. 
4.2 Calculation of Bank Asset Risk Under Ronn-Verma Option Pricing Methodology

\subsubsection{Data Analysis}

Extensive data on bank off-balance sheet activities (OBS) are available beginning in 1984. The initial sample utilized in this study consists of the 100 largest banks based on asset size which have continuous data over the years 1984 through 1988. Market values of equity (EQUTTY) for each bank or bank holding company are collected from COMPUSTAT yearly tapes. Daily bank stock returns and market returns are gathered from the CRSP and the NASDAO daily tapes. Data on off-balance sheet items are taken from the FDIC CaII and Income Reports for the lead bank of the holding company. The sample is restricted to those bank holding companies (BHC) whose lead bank accounts for the majority of consolidated holding company assets. The accounting risk variables defined in the previous section (LEV, DIV, AGAP, ALOSS, POR and ASIZE) are constructed from data collected from the FDIC yearly tapes. Data from the FDIC tapes, the COIPUSTAT tapes, the CRSP tapes and the NASDAQ tapes are merged together, and this resulted in a final sample of 32 banks and bank holding companies for 1984 through 1988. The relative size of market risk measures, accounting risk measures and OBS variables are shown in Table 3 .

\subsubsection{Calculation of Bank Asset of Risk}

SIGdLA1 is defined as the standard deviation of asset return and is calculated for each BHC for each year 1984 through 1988 using the RONN-VERIIA option pricing methodology. A system of tro non-linear simultaneous equations (equations (4) and (5) in Section 4) are solved for two unknowns, asset value (V) and the standard deviation of asset return (SIGIIA1), by a numerical routine for each observed yearly EOQCTTY and annualized standard deviation of equity return (SIGIAE). A subroutine, NEONF, in the International Nathematical and 
Statistical Library (IUSL) is used to solve the simultaneous equation system. The initial estimates used for the value, $V$, was the sum of the market value of equity and book value of debt, while that for $\sigma_{\mathrm{v}}$ was $\sigma_{\mathrm{E}}$ scaled down by the leverage ratio. The cumulative normal distribution function is calculated by using a polynomial approximation developed by Cox and Rubinstein (1985). Total liabilities, instead of insured debt liabilities, of BHCs are used for B in equations (4) and (5). This may be justified for two reasons. First, existing FDIC purchase and assumption policies extend, at least for larger banks, de facto accounting for such effects by on-balance sheet variables, and hence result in an overall reduction of risk.

SIGHA2 is calculated in the same way as SIGHA1, except that the leverage ratio is augmented by OBS debt. The mean value of ISGWA2 is smaller than that of SIGIA1. This can be explained by the call feature of equity value. As the face value of debt is augmented by OBS items, the value of equity decreases at the closure date. Because the call value is directly related to asset variance, a lower asset variance is associated with a decreased call value.

\subsubsection{Analysis of Results}

Table 4 presents estimates of explanatory variables using SIGlld1 as the dependent variable. SIGHA1 is the standard deviation of asset return calculated from Ronn-Verma option pricing methodology. All but one of the estimated coefficient of on-balance measures of risk have the expected signs. Leverage, diversification, credit risk and size (LEV, DIV, ALOSS and ASIZE) are statistically significant at the $1 \%$ level. Dividend payout ratio (POR) is not statistically significant. These results again are consistent with previous studies. 
The coefficients of four off-balance sheet variables (AOB, ACOMDI, APART and ASFAP) have unexpected positive signs but they are not statistically significant. The coefficients of two off-balance sheet variables (ASLC and ACLC) are significantly negative at the $5 \%$ and $1 \%$ levels respectively. It appears that risk-reducing diversification effects of Standby Letters of Credit (ASLC) and Commercial Letters of Credit (ACLC) dominate risk-increasing effects when SIGulA1 is used as the market measure of risk. The coefficient of total off-balance sheet items (AOBS) is, however, significantly positive at the $5 \%$ level. Therefore, it appears that total off-balance sheet items (AOBS) variable is risk-increasing with this particular risk measure.

Table 5 presents estimates of explanatory variables using SIGuL2 as the dependent variable. SIGiLA2 measures standard deviation of asset return from Ronn-Verma option pricing model when the leverage variable is increased by OBS variable. All but two coefficients of on-balance measures of risk have their expected signs. Leverage (LEV) is significantly positive at the $1 \%$ level. Size (ASIZE) is significantly negative at the $1 \%$ level. Interest rate risk and credit risk (AGAP and ALOSS) variables have unexpected negative signs but they are not significant.

All coefficients of off-balance measures of risk have expected negative signs and Commercial Letters of Credit (CLC) is significant at the $5 \%$ level.

4.3 Calculation of Bank Asset Risk Under Gorton-Santomero Subordinated Debt Option Pricing Methodology

\subsubsection{Data Analysis}

This research focuses on the 100 largest U.S. banks and BHCs, as these are only ones with publicly traded subordinated debt and debentures. Data on yield measures were gathered on all BHC for bank subordinated debt, debentures and 
capital notes which were publicly traded in the NYSE, AIEX, YASDAO with quoted sale and bid prices from Iloody's and Standard and Poor's bond manuals as of year ends 1984 through 1988. To make each BHC debt issue as homogeneous as possible: all zero coupon issues and floating rate issues were dropped from the sample. This produced 171 issues for $50 \mathrm{BHCs}$ in 1984, 137 issues for $49 \mathrm{BHCs}$ in 198.5, 160 issues for $48 \mathrm{BHCs}$ in 1986, 174 issues for $43 \mathrm{BHCs}$ in 1987 and 223 issues for 49 banks in 1988. Virtually all of these bonds were issued against the BHCs rather than the bank. There was a fair amount of heterogeneity in terms of maturity, coupons and issue size. Acquisitions or name changes of banks have been confirmed from Moody's Bank and Finance Manual in order to maintain continuity in data collection.

The risk-free rates of Treasury Securities identical in maturity to each debt issue were collected from lloody's Bond Record. Yields of multiple issues of a bank's subordinated debts are aggregated to calculate an average yield. Risk-premiums were calculated by simply subtracting risk-free rates of identical maturity from the yield measure. The risk-premium used in this study is the average premium of all outstanding issues for each BHC for each year. The on-balance and off-balance measures of risk are constructed as defined earlier, from variables available in the FDIC Call and Income Report for the years 1984 through 1988. The rish-premia of each BHC is matched against on-balance and off-balance measures of risk, and this resulted in a final sample of 32 banks and $\mathrm{BHCs}$ for each year. The relative size of market risk measures, accounting measures and OBS variables are show in Table 3. These rish-premia are then used as the dependent variables in regression analysis of on-balance and off-balance measures of bank risk. 


\subsubsection{Calculation of Bank Asset Risk}

The average risk-premium for each BHC for each year is used as the input in calculating each BHC's asset volatilities. Values of bank assets are market values of equity and book values of debt. The pricing formula (equation 1 ) is simply inverted to find asset volatility implied by the risk-premia. A Fortran program was written to solve for unknown asset variance in the non-linear equation of the subordinated debt pricing model. These implied variances were then used as the dependent variable in the regression analysis of on-balance and off-balance measures of bank risk.

Two asset variances were calculated. SIGMA1 treats bank debt as homogeneous, imposes a one-year maturity and uses subordinated debt to assets less insured debt as the leverage variable. SIGuld2 is the same as SIGMA1, except that the leverage variable is subordinated debt plus OBS debt to assets minus insured debt, because not all risks assumed by a bank appear on its balance sheet. Results are presented using both measures of risk, and they are generally consistent.

\subsubsection{Analysis of Results}

Table 6 reports the results of regression coefficients when the dependent variable is the direct risk measure. SIGUL1 is the implied asset variance derived from a subordinated debt option pricing model. Again all of the off-balance sheet variables have negative coefficients. Four out of seven estimated coefficients are significant at the $1 \%$ level (AOB, ASLC, ASWAP, AOBS); one is significant at the $5 \%$ level (APART), one is significant at the $10 \%$ level (ACOMII), and the coefficient of ACLC is not significantly different from zero. These results again support the risk-reducing nature of OBS banking activities. The expected positive coefficient for leverage (LEV) and expected negative 
coefficient for diversification (DIV) along with negative coefficients of OBS variables also suggest that rish-reducing diversification impacts of OBS activities dominates risk-increasing impact of these activities.

All coefficients of the on-balance measures of accounting risk variables except one have the expected sign. The coefficients on interest rate risk (AGAP) are significantly positive. The coefficients on credit risk (ALOSS) have the wrong sign and this is likely due to the multicollinearity between credit risk and interest rate risk (ALOSS and AGAP) variables. The coefficients on size (ASIZE) are significantly negative. The coefficients on dividend payout ratio (POR) are not significantly different from zero.

Table 7 presents the coefficient estimates of off-balance and on-balance measures of bank risk using SIGWL2 as the dependent variable. SIGUL2 is similar to SIGMIA1 except that the leverage variable was augmented by OBS debt in the subordinated debt option pricing model. The coefficients of all OBS variables except one have negative signs. Two of these coefficients are significant at the $1 \%$ level (ASLC, ACLC). The coefficients of five OBS variables (AOB, ACOACI, APART, ASWAP, AOBS) are not significantly different from zero. These results suggest that at least some of the OBS variables are risk-reducing. A11 estimated coefficients of on-balance measures of risk have the expected signs; and all but two are statistically significant at the $5 \%$ level.

The regression results for both measures of asset risk (SIGuld and SIGild2) are consistent with the results of Gorton and Santomero (1989) for on-balance measures of risk but extends these results to off-balance measures of risk. The results are very similar to the risk-premia model and suggest that a market discipline exists for OBS banking activities, and subordinated debtholders vier these OBS activities of large commercial banks as risk-reducing. 
V. Conclusions and Policy Implications

"Harket discipline" studies of OBS banking risk have addressed the question of whether market prices of bank equities and liabilities reflect the risk of OBS activities. The standard approach to determine whether market prices of uninsured equity and debt contain individual bank risk-premia is to regress the equity variance of yield spread against on-balance and off-balance measures of risk. To date these results have been mixed. The uninsured bank equity and debt liabilities are subordinated claims which are not linear or monotonic functions of bank risk premia. Horeover, the underlying risk is dependent upon the regulatory closure rule. Fithout recognizing these complications linear equity variance and risk-premia regressions may be inadequate in addressing the "market discipline" question.

The "market discipline" of OBS banking activities has been reexamined by using contingent claims valuation models to derive explicit pricing formulae which incorporates regulatory closure rules for bank subordinated debt (Gorton-Santomero, 1989) and bank equity with deposit insurance (Ronn-Verma, 1986). Specifically, implied variances have been calculated and regressed over on-balance and off-balance measures of bank risk. These implied asset variances are better than equity variance or risk-premia in proxying total risk because they consider both the nonlinear nature of contingent claims model and the impact of closure rules.

The major empirical findings of this study can be summarized as follows. All seven off-balance measures of risk in this study are risk-reducing depending on the proxy used for total risk. Four off-balance sheet items (AOBS, ACLC, ASLC and ACOAd) are always risk-reducing regardless of the proxy used for total risk. 
Several on-balance measures of accounting risk also shor statistically significant correlations with market measures of risk. The pooled cross-section and time-series analysis of OBS banking risk provides better coefficient estimates (increased t-statistics) and increases the statistical significance of models (increased F-statistics).

The existing policy proposal to regulate OBS banking risk by bringing them into a risk-based capital requirement can be analyzed in the light of empirical findings of this research. The results indicate that off-balance sheet activities, in general, reduce total risk. Thile bank regulators are concerned with total risk and the probability of bank failures, the risk-reducing potential of OBS activities indicates that additional capital requirement of OBS banking activities will penalize large banks.

There is clear evidence of a "market discipline" of OBS banking risk. Warket participants price these OBS activities as risk-reducing. Therefore, regulatory interferences in the form of additional capital requirement of OBS activities are likely to create distortions in the financial intermediation market. 
REFERENCES

1. Avery, Robert B. and Allen N. Berger (1988), "Risk-based Capital and Off-Balance Activities," Proceedings of a Conference on Bank Structure and Competition, Federal Reserve Bank of Chicago, pp. 261-287.

2. Avery, Robert B., Terrence I. Belton, and Michael A. Goldberg (1988), "Market Discipline in Regulating Bank Risk: New Evidence from the Capital Markets," Journal of Honev. Credit and Banking (June).

3. Baer, Herbert and Elijah Brewer (1986), "Uninsured Deposits as a Source of llarket Discipline: Some New Evidence," Economic Perspectives

(September/October), Federal Reserve Bank of Chicago, pp. 23-31.

4. Berger, Allen N. and L. Benveniste (1986), "An Empirical Analysis of

Standby Letters of Credit," Proceedings of a Conference on Bank Structure and Competition, Federal Reserve Bank of Chicago, pp. 387-412.

5. Black, F. and II. Scholes, "The Pricing of Options and Corporate Liabilities," Journal of Political Economv 81 (Nay 1973), pp. 637-59.

6. Brewer, E., G. Koppenhaver, and D. Wilson (1986), "The Harket Perception of Bank Off-Balance Sheet Activities," Proceedings of a Conference on Bank Structure and Competition, Federal Reserve Bank of Chicago, pp. 412-436.

7. Chang, Hui-Shyong and Cheng-Few Lee, "Using Pooled Time-Series and Cross-Section Data to Test the Firm and Time Effects in Financial Analyses," Journal of Financial and 0mantitative Analvsis, 12 (September $1977)$, pp. $457-471$

8. Cramer, Robert H. and Robert J. Rogowski (1985), "Risk Premia on Negotiable Certificates of Deposit and the Continental Illinois Bank Crisis," mimeo.

9. Goldberg, Michael A. and Peter R. Llovd-Davies (1985), "Standby Letters of Credit: Are Banks 0verextending Themselves," Journal of Bank Research 16 (Spring), pp. 29-39.

10. Gorton, Gary and Anthony II. Santomero (1989), "Warket Discipline and the Valuation of Bank Subordinated Debt," The Wharton School, University of Pennsylvania, mimeo.

11. Hannan, Timothy and Gerald Hanweck (1988), "Bank Insolvency Risk and the Harket for Large Certificates of Deposits," Journal of llonev. Credit and Banking (May).

12. Hassan, M. Kabir, "Off-Balance Sheet Items and Risk-Taking Behavior of Commercial Banks," 1990 Working Paper, Presented at the 1990 Annual Jeetings of Financial Management Association Heetings: 
13. Hassan, M. Kabir. Gordon V. Karels and Hanferd O. Peterson, "The Varket's Evaluation of Off-Balance Sheet Banking Risk: \$ Methodological

Reexamination," 1990 Forking Paper, Paper presented at the 1990 Innual Meetings of Financial Hanagement Association Meetings.

14. Jahankhani, Ali and Horgan J. Lynge (1980), "Commercial Bank Financial Policies and Their Impact on Market-Determined Risk," Jonrnal of Bank Research, 11:3 (Autumn), pp. 169-178.

15. Koppenhaver, G.D. (1987), "Standby Letters of Credit," Economic Perspectives, Federal Reserve Bank of Chicago, July-dugust, pp. 28-38.

16. Lee, Cheng-Few and Elijah Brewer (1987), "The Association Between Bank Stock Market-Based Risk Measures and the Financial Characteristics of the Firm: A Pooled Cross-Section and Time-Series Approach," Proceedings of $\underline{a}$ Conference on Bank Structure and Competition, Federal Reserve Bank of Chicago, pp. $2 \overline{85-315 .}$

17. Lynge, Morgan and Cheng-Few Lee (198T), "Total Risk, Systematic Risk, and Off-Balance Sheet Risk for Large Commercial Banks," WPP, University of Illinois at Urbana-Champaign.

18. Herton, Robert C. (1978), "On the Cost of Deposit Insurance When There are Surveillance Costs," Journal of Business 51 (3), pp. 439- 76 .

19. Merton, Robert C. (1974), "On the Pricing of Corporate Debt: The Risk Structure of Interest Rates," Jomrnal of Einance 19 (Hay); pp. 449-70.

20. Pavel, Christine (1988), "Loan Sales Ilave Little Effect on Bank Risk," Economic Perspectives, Federal Reserve Bank of Chicago, 12, pp. 23-31.

21. Pavel, Christine and David Philis (1987), "Thy Commercial Banks Sell Loans: An Empirical Analysis," Economic Perspectives, Federal Reserve Bank of Chicago, 11, pp. 3-14.

22. Pennachi, George C. (1987), "A Reexamination of the Over- (or Under) Pricing of Deposit Insurance," Jonrnal of llonev. Credit and Banking, 19 (3), (August), pp. 340-60.

23. Pettway, Richard H. (1976), "Jlarket Tests of Capital ddequacy of Large Commercial Banks," Jomrnal of Finance (June).

24. (1976a), "The Effects of Large Bank Failures Upon Investors' Risk

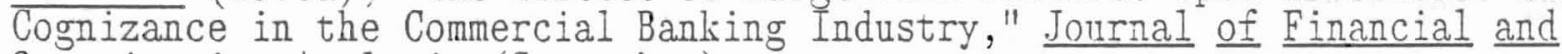
Dlantitative Analvsis (September).

25. Ronn, Ehud and A. K. Verma (1985), "Pricing Risk-adjusted Deposit Insurance: An option-based Hodel," Jonrnal of Finance, 41:4, (September). 
TABLE 1

AGGREGATE VOLUME OF OFF-BALANCE-SMEET COMUTHENTS AND CONTINGENCIES

U.S. COMMRCIAL BANKS

ANNUAL DATA AS OF DECEMBER, IN BILLIONS OF DOLLARS

\begin{tabular}{|c|c|c|c|c|c|}
\hline & 1984 & 1985 & 1986 & 1987 & 1988 \\
\hline Commitments to Lend & 495.6 & 542.4 & 570.4 & 611.6 & 654.9 \\
\hline $\begin{array}{l}\text { Futures and forward contracts (exclude FX) } \\
\text { Commitments to buy } \\
\text { Commitments to sell }\end{array}$ & $\begin{array}{l}40 \\
28.3\end{array}$ & $\begin{array}{l}57.2 \\
40.5\end{array}$ & $\begin{array}{l}99.7 \\
79.6\end{array}$ & $\begin{array}{l}122.7 \\
137.6\end{array}$ & $\begin{array}{l}174.3 \\
234.4\end{array}$ \\
\hline $\begin{array}{l}\text { When issued securities } \\
\text { Commitments to buy } \\
\text { Commitments to sell }\end{array}$ & $\begin{array}{l}4.3 \\
3.5\end{array}$ & $\begin{array}{l}4.4 \\
3.3\end{array}$ & $\begin{array}{l}9.8 \\
6.2\end{array}$ & $\stackrel{2}{2.1}$ & $\begin{array}{l}6.8 \\
6.6\end{array}$ \\
\hline $\begin{array}{l}\text { Standby contracts \& other option contracts } \\
\text { Obligations to buy under option contract } \\
\text { Obligations to sell under option } \\
\text { contracts }\end{array}$ & $\begin{array}{r}2.8 \\
1.7\end{array}$ & $\begin{array}{c}10.7 \\
5\end{array}$ & $\begin{array}{l}27.8 \\
11.8\end{array}$ & $\begin{array}{l}48.9 \\
16.4\end{array}$ & $\begin{array}{l}67.3 \\
29.4\end{array}$ \\
\hline $\begin{array}{l}\text { Commitments to buy FX (incl. SUS), spot } \\
\text { \& forward }\end{array}$ & 584 & 735.2 & 890.8 & $1,504.1$ & $1,683.2$ \\
\hline $\begin{array}{l}\text { Standby L/C and foreign office guarantees } \\
\text { To U.S. addressees } \\
\text { To Non-U.S. addressees } \\
\text { (Amount of these items sold to others }\end{array}$ & $\begin{array}{c}109.8 \\
34\end{array}$ & $\begin{array}{r}134.8 \\
38.2\end{array}$ & $\begin{array}{r}132.1 \\
35.8\end{array}$ & $\begin{array}{r}134.5 \\
33.7\end{array}$ & $\begin{array}{r}135.6 \\
33.2\end{array}$ \\
\hline via participations) & 15 & 18.2 & 18.5 & 19.6 & 19.2 \\
\hline Commercial $\mathrm{L} / \mathrm{C}$ & 30 & 28.4 & 28.4 & 30.5 & 30.2 \\
\hline $\begin{array}{l}\text { Participations in acceptances sold to } \\
\text { others }\end{array}$ & 8.4 & 8.4 & 5.4 & 4.2 & 3.9 \\
\hline $\begin{array}{l}\text { Participations in acceptances bought } \\
\text { from others }\end{array}$ & 1.5 & 0.9 & 0.8 & 1.5 & 0.5 \\
\hline Securities borrowed & 2.7 & 3.5 & 5.4 & 5.9 & 6.7 \\
\hline Securities lent & 2.2 & 3.1 & 4 & 4.5 & 3.9 \\
\hline $\begin{array}{l}\text { her significant } c \\
\text { ntingencies }\end{array}$ & 24.5 & 57.7 & 70.5 & 84.3 & 128.1 \\
\hline
\end{tabular}


Table 1, continued

$\begin{array}{lllll}1984 & 1985 & 1986 & 1987 & 1988\end{array}$

Memoranda:

Loans originated \& sold during period ending this quarter

$\begin{array}{lllll}50.1 & 75.6 & 107.7 & 192.1 & 280.4\end{array}$

Loans purchased during period ending

this quarter

$\begin{array}{lllll}\mathrm{n} / \mathrm{a} & \mathrm{n} / \mathrm{a} & \mathrm{n} / \mathrm{a} & 15.7 & 18.7\end{array}$

Notational value of all outstanding interest rate swaps

n/a $\quad 186.1 \quad 366.6 \quad 714.9 \quad 928.6$

Hortgages sold, with recourse

FNMIA \& FHLUC residential mortgage loan pools

$0 / \mathrm{S}$ principal bal. of mortgages sold or swapped mortgages

$\mathrm{n} / \mathrm{a}$

$\mathrm{n} / \mathrm{a}$

$\mathrm{n} / \mathrm{a}$

$\mathrm{n} / \mathrm{a}$

$\mathrm{n} / \mathrm{a}$

$\mathrm{n} / \mathrm{a}$

$\mathrm{n} / \mathrm{a}$

$\mathrm{n} / \mathrm{a}$

$n / a$

$\mathrm{n} / \mathrm{a}$

Private residential mortgage loans 0/S principal bal. of mortgages sold Amount of recourse exposure on these mortgages

$\mathrm{n} / \mathrm{a}$

$\mathrm{n} / \mathrm{a}$

$\mathrm{n} / \mathrm{a}$

$\mathrm{n} / \mathrm{a}$

$\mathrm{n} / \mathrm{a}$

$\mathrm{n} / \mathrm{a}$

$\mathrm{n} / \mathrm{a}$

$n / a$

$\mathrm{n} / \mathrm{a}$

$\mathrm{n} / \mathrm{a}$

$\mathrm{n} / \mathrm{a}$

$\mathrm{n} / \mathrm{a}$

$\mathrm{n} / \mathrm{a}$

$\mathrm{n} / \mathrm{a}$

$\mathrm{n} / \mathrm{a}$

Farmer Hac agricultural mortgage loan pools $0 / \mathrm{S}$ principal bal. of mortgages sold $\mathrm{n} / \mathrm{a}$ Amount of recourse exposure on these mortgages

$n / a \quad n / a \quad n / a \quad n / a \quad n / a$

$\mathrm{n} / \mathrm{a} \quad \mathrm{n} / \mathrm{a} \quad \mathrm{n} / \mathrm{a} \quad \mathrm{n} / \mathrm{a} \quad \mathrm{n} / \mathrm{a}$

Total, excluding memoranda items $\quad \begin{array}{llllll}1,438.4 & 1,953.6 & 2.471 .3 & 3,686.8 & 4,445.9\end{array}$

Total assets (on-balance-sheet items) $\quad 2,492.5 \quad 2,707.6 \quad 2,907.5 \quad 2,955.2 \quad 3,064.2$

Source: Call Reports (0CC, Ogilvie, October 1990).

Notes:

1. $\mathrm{FX}=$ foreign exchange

2. $\mathrm{L} / \mathrm{C}=$ Letter of credit

3. /S principal bal. = outstanding principal balance 
Table 2

OBS Items (Schedule RC-L Off-Balance Sheet Variables)

1. Securities borrowed

2. Securities lent

3. Commitments to purchase when issued securities

4. Commitments to sell when issued securities

5. Notational value of interest rate swaps

6. SLC to U.S. addresses

7. SLC to non U.S. addresses

8. SLC participated to others

9. Commercial letters of credit

10. Commitments to purchase foreign currencies

11. Unused loan commitments

12. Commitments to purchase futures and forward contracts

13. Commitments to sell futures and forward contracts

14. Obligation to purchase under option contracts

15. Obligations to sell under options contract

16. Participations in acceptances conveyed to others

17. Participations in acceptances conveyed from others

18. Other significant commitments or contingencies

19. Loan sold or participated to others

The off-balance sheet variables consist of the following items:

$\mathrm{OB}=3+6+7-8-9+10+11$

COMI $=12+13+14+15+18$

PART $=8+16+17+19$

SWAP $=5$

SLC $\quad=6+7-8$

CLC $\quad=9$

OBS $=O B+$ COADI + PART + STHP + SLC + CLC 


\section{Table 3}

Sumary Statistics for Accounting Risk Variables, Off-Balance Sheet Variables and Market Measures of Risk Variables ${ }^{a}$

\begin{tabular}{|c|c|c|c|}
\hline$\underline{\text { Variable }}$ & $\underline{\text { Svmbol }}$ & $\underline{\text { Mean }}$ & $\begin{array}{l}\text { Standard } \\
\text { Deviation }\end{array}$ \\
\hline Asset Risk (RV) & SIGIIA 1 & .00155 & .00179 \\
\hline Asset Risk (RV) & SIGMIA 2 & .00065 & .00208 \\
\hline Asset Risk (GS) & SIGHA 3 & 1.55564 & .35084 \\
\hline Asset Risk (GS) & SIGIIA 4 & .01470 & .05095 \\
\hline Off-balance sheet groups & $\mathrm{AOB}$ & .97779 & .94551 \\
\hline Commitments & ACOIN & .16469 & .24067 \\
\hline Participations & APART & .09618 & .27160 \\
\hline National Value of Swaps & ASWAP & .32129 & .52079 \\
\hline Commercial Letters of Credit & ACLC & .01523 & .01095 \\
\hline Standby Letters of Credit & ASLC & .07394 & .04687 \\
\hline Total Off-Balance Items & AOBS & 1.58013 & 1.69662 \\
\hline Financial Leverage & LEV & .94938 & .01317 \\
\hline Diversification Index & DIV & 1.74527 & .67445 \\
\hline Credit Risk & ALOSS & .01341 & .00956 \\
\hline Interest Rate Risk & $A G A P$ & .05955 & .13878 \\
\hline Dividend Payout Ratio & POR & .50910 & .74757 \\
\hline Logarithm of Assets & ASIZE & 16.65717 & .99929 \\
\hline
\end{tabular}


TABLE 4

Pooled Cross-Sectlon and Ime-Serles Results

\begin{tabular}{|c|c|c|c|c|c|c|c|c|c|c|c|c|c|c|c|c|}
\hline $\begin{array}{l}\text { Equact lons } \\
\quad \text { Ho. }\end{array}$ & Consisnt & LOH & ACOHM & APART & $\Lambda s ! c$ & ActC & $\triangle S H A P$ & SOHS & LEX & DIY & drAP & H. .0 SS & PQR & ASIZE & $\bar{n}^{2}$ & $F(8,152)$ \\
\hline 1 & $(6.69)^{.043}$ & $\begin{array}{l}.00008 \\
(.81) .\end{array}$ & - & - & - & $\underline{\cdots}$ & - & $\overline{-}$ & $\frac{.033}{(4.89)^{x+4}}$ & $\begin{array}{c}-.00023 \\
(-2,17)^{\star A A A}\end{array}$ & $\frac{-.000003}{(-2.13)^{\star \star}}$ & $\frac{.023}{(2.74)^{* \times 4}}$ & -.000004 & $\begin{array}{c}-.0006 \\
(-6.83) \times A 4\end{array}$ & .43 & $16.32 \mathrm{AkA}$ \\
\hline 2 & $(6.98) \approx A A$ & - & $(.0002$ & $\cdots$ & -- & -- & -- & -- & $(5.23) \times A n$ & $\begin{array}{l}-.0003 \\
(-2.68) \text { AnA }\end{array}$ & $\frac{-.000002}{(-1.64)^{k}}$ & $(4.033) \mathrm{AnA}$ & -.0000005 & $\begin{array}{l}-.0005 \\
(-6.40)^{\star \star \star k}\end{array}$ & .41 & $.15 .02 \mathrm{An}$ \\
\hline 3 & $(6.63)^{\star 04 \times n}$ & -- & - & $\because(.80)$ & -- & $\cdots$ & -- & $\cdots$ & $\begin{array}{c}.034 \\
(5.10)^{\text {ath }}\end{array}$ & $\begin{array}{l}-.0002 \\
(-2.34)_{\text {Anan }}\end{array}$ & $\begin{array}{l}-.000003 \\
(-2.04)^{\text {An }}\end{array}$ & $\frac{.025}{(3.64)^{\mathrm{AnAh}}}$ & -.000004 & $\begin{array}{c}-.0005 \\
(-9.07)^{\text {AnA }}\end{array}$ & .44 & $17.26 \mathrm{AnA}$ \\
\hline 4 & $(5.90)^{t \times A n}$ & - & -- & - & $(-1.53) *$ & -- & $\cdots$ & - & $\frac{.036}{(5.01)^{A+A}}$ & $\begin{array}{l}-.0003 \\
(-3.17)^{\text {AfAk }}\end{array}$ & $\begin{array}{l}-.000003 \\
(-1.92)^{\star \star}\end{array}$ & $(3.027)^{\text {AaA }}$ & $\frac{-.000002}{(-.28)}$ & $\frac{-.0004}{(-3.52)^{\mathrm{AnA}}}$ & .43 & $16.21 \mathrm{AnA}$ \\
\hline 3 & $\begin{array}{c}.040 \\
(5.91)^{A 4 A A}\end{array}$ & - & - & -- & - & $\begin{array}{c}-.023 \\
(-3.61)^{\text {AaA }}\end{array}$ & - & -- & $\frac{.033}{(4.64) \text { aAnA }}$ & $\begin{array}{l}-.0002 \\
(-i .76)^{\mathrm{An}}\end{array}$ & $\begin{array}{l}-.000002 \\
(-1.50)^{n}\end{array}$ & $(5.00)^{a+A n}$ & -.0000004 & $\begin{array}{c}-.0004 \\
(-5.36) \text { AAA }\end{array}$ & .41 & $15.06 \mathrm{AnA}$ \\
\hline 6 & $(6.32)$ AAA & -- & $\div$ & -- & - & -- & $\left(i^{0.0022}\right.$ & $\cdots$ & $(4.70)^{.033}$ & $\begin{array}{l}-.0002 \\
(-2.21)^{* 4}\end{array}$ & -.000003 & 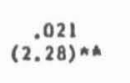 & -.000003 & $(-7.78)^{\text {Ankn }}$ & .42 & 15.07 . AnA \\
\hline 7 & $\frac{(.042) *}{(6.55)^{\star A * A}}$ & - & - & -- & - & -- & -- & (i.37)" & $\frac{.032}{(6.79)^{4 \star A}}$ & $\begin{array}{l}-0002 \\
(-2.11)^{\text {An }}\end{array}$ & $\frac{-.000003}{(-2.15)^{A A}}$ & $(2.020$ & -.000004 & $\frac{-.00062}{(-7.39)^{n k A}}$ & .43 & $16.33 \mathrm{Am}$ \\
\hline
\end{tabular}

HOTES: 1) SIGMA Is the annuallized standard deviation of asset returns

calculated from Ronn-Verms (1986) optlon pricing methodologyi

2) AOB, ACONW, APART, ASIC, ACLC, ASWAP and AOBS represent seven

3) LEV, DIV, AGAP, ALOSS, POR and ASIZE represent flananclal leverage diversiflcatlon index, Interest rate rlsk, credit rlsk.

1) Humbers in the and logarltim of assets respectively;

5) Significance level: $n=10 x_{;} n=5 x_{i} \cdot n a=1 x$. 
TABLE 5

Pooled Cross-Sectlon and IIme-Serles Results
(Dependent Vartable: SIGHaz)

\begin{tabular}{|c|c|c|c|c|c|c|c|c|c|c|c|c|c|c|c|c|}
\hline $\begin{array}{c}\text { Equat tone } \\
\text { lis. }\end{array}$ & Constant & $\mathrm{SOH}$ & $\triangle \mathrm{COH} M$ & APART & As!G & ACLC & ASHAP & AOBS & IEY & DIY & $\triangle G Q P P$ & N.OSS & $\mathrm{PQR}$ & ASIZE & $\bar{B}^{2}$ & $F(\theta, 152)$ \\
\hline 1 & $(4.70)^{\text {AnAk }}$ & -.00004 & -- & -- & - & - & -- & - & ${ }_{(3.29)^{A 4 A}}^{.018}$ & $\begin{array}{l}-.00013 \\
(-1.05)\end{array}$ & -.000001 & $\begin{array}{l}-.0019 \\
(-.29)\end{array}$ & $\begin{array}{r}-.000004 \\
(-.41)\end{array}$ & $\begin{array}{c}-.0004 \\
(-3.39)^{\text {A.AA }}\end{array}$ & .30 & $9.50 \mathrm{kAn}$ \\
\hline 2 & $(4.26)^{A 4 A 4}$ & -- & -.00003 & - & - & $\ldots$ & -.. & -- & $\begin{array}{c}.015 \\
(2.91)^{A A M A}\end{array}$ & $-(-.00009$ & $-(-1.11)$ & $\frac{7.0054}{(-.76)}$ & $\begin{array}{r}-.000006 \\
(-.86)\end{array}$ & $\frac{-.0004}{(-6.09) A A A}$ & .29 & $8.68 \mathrm{AAA}$ \\
\hline 3 & $(5.41)^{\text {Anak }}$ & - & - & $\begin{array}{r}-.00008 \\
(-.43)\end{array}$ & -- & - & --- & - & $(3.95)^{.017}$ & -.00008 & $-\frac{.000001}{(-1.08)}$ & $\begin{array}{l}-.0033 \\
(-.64)\end{array}$ & $\begin{array}{r}-.000004 \\
(-.48)\end{array}$ & $\begin{array}{l}-00047 \\
(-4.81)^{\text {AAk }}\end{array}$ & .34 & 10.87 Aak \\
\hline 4 & $\begin{array}{c}.024 \\
(3.80) \text { AAn }\end{array}$ & -- & - & -- & $\begin{array}{l}-.0013 \\
(-.53)\end{array}$ & $\ldots$ & - & - & $\frac{.016}{(2.63)^{A \times A}}$ & $\begin{array}{r}-.00012 \\
(-.99)\end{array}$ & $-(-1.13)$ & $\begin{array}{r}-.0034 \\
(-.62)\end{array}$ & $\begin{array}{r}-.000002 \\
(-.26)\end{array}$ & $\begin{array}{c}-.00048 \\
(-3.57)^{\text {AnA }}\end{array}$ & .30 & $9.12 \mathrm{AAn}$ \\
\hline$s$ & $\begin{array}{c}.026 \\
(5.05)^{A A n}\end{array}$ & -- & - & - & $\ldots$ & $\begin{array}{l}-.013 \\
(-2.22) \star k\end{array}$ & - & - & $\begin{array}{l}.018 \\
(3.70)^{\text {AAAA }}\end{array}$ & -.00007 & $\frac{-.000002}{(-i .96)^{A A *}}$ & $\begin{array}{r}-.004 \\
(-.80)\end{array}$ & -.000003 & $\begin{array}{l}-.00043 \\
(-4.03) \mathrm{kman}\end{array}$ & .32 & 10.24 *A \\
\hline 6 & $\begin{array}{c}.024 \\
(4.50)^{\text {AnA A }}\end{array}$ & - & $\cdots$ & - & - & -- & $-\frac{.00002}{(-.13)}$ & -. & $\begin{array}{l}.016 \\
(3.04)^{\mathrm{AnAA}}\end{array}$ & -.00011 & -.000001 & $\begin{array}{r}-.005 \\
(-.62)\end{array}$ & $\begin{array}{r}-.000004 \\
(-.52)\end{array}$ & $\begin{array}{l}-0.00043 \\
(-3.96) * A 4\end{array}$ & .31 & $9.70 \mathrm{AnA}$ \\
\hline 7 & $(4.56)^{\text {AnA }}$ & - & $\ldots$ & -- & - & - & $\ldots$ & -.00003 & $\begin{array}{c}018 \\
(3: 09)^{A a k}\end{array}$ & $\begin{array}{r}-.00013 \\
(-1.03)\end{array}$ & $\begin{array}{r}.000001 \\
(-1.09)\end{array}$ & $\begin{array}{l}-.0015 \\
(-.19)\end{array}$ & -.000003 & $\begin{array}{l}-00043 \\
(-3.27)^{A \times A 4}\end{array}$ & .31 & $9.81 \mathrm{AnA}$ \\
\hline
\end{tabular}

MOIES: i) SIGHaz is the annuallized standard devlation of asset returns calculated from Ron-Yerma (1986) optlon pricing methodology whien

2)

3) IEV, DIV, AGAP, ALOSS, POR and ASIZE represent flananclal leverage, diversificatlon index interest rate risk. credli risk.

1) Mumbers in the parentheses are t-statisticsi 
TABLE 6

Pooled Cross-Sectlon and TIme-Serles Results
(Dependent Varlate: SIMaj)

\begin{tabular}{|c|c|c|c|c|c|c|c|c|c|c|c|c|c|c|c|c|}
\hline $\begin{array}{c}\text { Equactions } \\
\text { Ho. }\end{array}$ & Conersant & 으은 & SCOANM & APABAT & 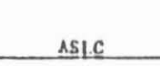 & AGle & $\triangle S H A P$ & Sars & LEX & DIX & DeAP & Hoss & POR & ASIZE & $-\bar{R}^{2}$ & $E(\underline{B}, \mid \leq 2)$ \\
\hline 1 & (3.3i) 3.66 Ant & $\begin{array}{l}-.048 \\
(-2.95) \times A k A\end{array}$ & - & -- & - & - & -- & 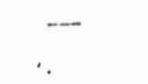 & (.67) & $(-12.42)^{-2 k \hbar k}$ & $\frac{.0004}{(2 ; 68)^{\text {AnA A }}}$ & $(-4.28)^{-5 \mathrm{AnA}}$ & $(i .47) *$ & $\begin{array}{l}-.10 \\
(-5.51) \text { ank }\end{array}$ & .79 & $69.20 \mathrm{AnA}$ \\
\hline 2 & $\begin{array}{c}3.48 \\
(2.63) \mathrm{AAA}\end{array}$ & -- & $(-1.37)^{\mathrm{A}}$ & -- & -- & -- & -- & -- & $i^{.038}$ & $(+11.39)^{-.24 A A}$ & $\frac{.00023}{(.78)}$ & $(-4.32)^{-6.84}$ & (.0017) & $\begin{array}{c}-.13 \\
(-5.88) \text { AAA }\end{array}$ & .73 & 49.90 AAA \\
\hline 3 & $\begin{array}{c}3.25 \\
(2.50)^{A A B A}\end{array}$ & - & - & $(-2.10)^{\text {kn }}$ & - & $\ldots$ & -- & - & (.27) & $\begin{array}{c}-.24 \\
(-11,04)^{* \hbar k}\end{array}$ & $\frac{.00025}{(.85)}$ & $\begin{array}{c}-6.90 \\
(-4.46) * \hbar k\end{array}$ & $\begin{array}{l}.0018 \\
(.80)\end{array}$ & $\begin{array}{l}-.13 \\
(-6.40) \text { \#A }\end{array}$ & .72 & $46.53 \mathrm{Ank}$ \\
\hline 4 & $\underset{(1.64) \mathrm{An}}{2.22}$ & - & - & - & $\begin{array}{l}-1.27 \\
(-3.66) \mathrm{Akh}\end{array}$ & - & -- & - & $\begin{array}{l}.85 \\
(, 63)\end{array}$ & $\begin{array}{c}-.23 \\
(-10.91)^{\mathrm{AAB}}\end{array}$ & $\frac{.0002}{(.72)}$ & $\begin{array}{c}-7.66 \\
(-5.20)^{\text {kAk }}\end{array}$ & $\begin{array}{l}.002 \\
(.95)\end{array}$ & $\begin{array}{l}-.10 \\
(-3.48) \text { ank }\end{array}$ & .76 & $56.25 \mathrm{AAA}$ \\
\hline$s$ & $\begin{array}{c}4.53 \\
(3.94) \mathrm{AnAA}\end{array}$ & $\ldots$ & . - & - & -- & $\begin{array}{l}-.63 \\
(-.64)\end{array}$ & - & $\ldots$ & $\begin{array}{l}.97 \\
(.80)\end{array}$ & $\left(-12, i^{26}\right)_{\star \star A k}$ & $(2.37)_{\text {AaA A }}$ & $\begin{array}{l}-7.28 \\
(-5.55)^{* \ldots * k}\end{array}$ & $\begin{array}{l}.0028 \\
(1.24)\end{array}$ & $\begin{array}{l}-.14 \\
(-9.31) \ldots \mathrm{An}\end{array}$ & .80 & $\therefore 2.18 \mathrm{AkA}$ \\
\hline 6 & $\begin{array}{l}5.08 \\
(4.82) A A A\end{array}$ & - & - & --- & - & - & $\begin{array}{l}-.12 \\
(-3.87)^{\text {AAA }}\end{array}$ & -.- & $\begin{array}{l}1.94 \\
(1.68) \times n\end{array}$ & $(-12.68)^{-.23 A A}$ & $(2.73)^{\text {AtA A }}$ & $\begin{array}{c}-3.77 \\
(-2.36) \star A A\end{array}$ & (1.21) & $(-7.12$ & .82 & $84.22 \mathrm{AmA}$ \\
\hline 7 & $\begin{array}{c}3.39 \\
(2.72)^{4 A x}\end{array}$ & -- & - & - & - & -- & -- & $\begin{array}{c}-.038 \\
(-3.18) A \times A\end{array}$ & $(.37)$ & $(-11.83)^{\text {AnA }}$ & . & $(-2.73)^{-4.71}$ & $\begin{array}{l}.0018 \\
(.81)^{2}\end{array}$ & $\begin{array}{l}-.11 \\
(-4,37) \star \pi n\end{array}$ & .75 & $55.83 \mathrm{AAA}$ \\
\hline & HOTES: & 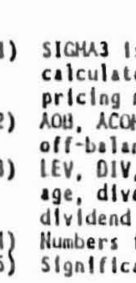 & $\begin{array}{l}\text { S the annua } \\
\text { ed from Gor } \\
\text { mathodology } \\
\text { MH, APART, } \\
\text { ace sheet } \\
\text { AGAP, ALO } \\
\text { ersificallor } \\
\text { payout and } \\
\text { In the pare } \\
\text { ance level: }\end{array}$ & 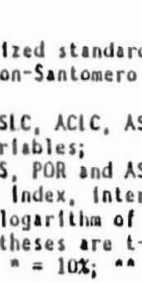 & 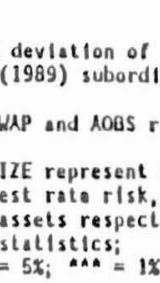 & $\begin{array}{l}\text { ssat retu } \\
\text { ated debt } \\
\text { present } \\
\text { Inanclal } \\
\text { credit } r \mid \\
\text { velyi }\end{array}$ & $\begin{array}{l}\text { ns } \\
\text { optlon } \\
\text { ven } \\
\text { lever- } \\
k_{0}\end{array}$ & . & & & . & & & & & \\
\hline
\end{tabular}


TABLE 7

Pooled Cross-Sectlon and IIme-Serles Results
(Dependent Varlable: SIGMA)

\begin{tabular}{|c|c|c|c|c|c|c|c|c|c|c|c|c|c|c|c|c|}
\hline $\begin{array}{c}\text { Equattons } \\
\text { He. }\end{array}$ & Conatant & 애으 & $\Delta C O A M$ & $\triangle P A R T$ & $\Lambda S I C$ & $\triangle C I C$ & $\triangle S H A P$ & sons & LEV & DIY & SGSP & NOSS & $\mathrm{POB}$ & ASIIZE & $\bar{B}^{2}$ & $P(\underline{\theta}, 1 \leq 2)$ \\
\hline I & $\left(\begin{array}{l}.17 \\
(1.55) *\end{array}\right.$ & $\begin{array}{l}-.0001 \\
(-.51) .\end{array}$ & - & - & - & - & - & - & $(1.13)$ & $\begin{array}{r}-.0038 \\
(-1.53)^{4}\end{array}$ & $(i, 02)^{\text {\#\# }}$ & i. & $\begin{array}{l}.0000012 \\
(.012)\end{array}$ & $\frac{-.0033}{(-i .69)^{\mathrm{AAB}}}$ & .16 & $4.36 * 0$ \\
\hline 2 & $(1.78) \times A$ & - & $\begin{array}{l}-.00041 \\
(-.14)\end{array}$ &. & - & - & - & - & $\frac{.15}{(1.31) *}$ & $(-1.07)^{4 \text { Ak }}$ & $\frac{.00012}{(2.00)^{\text {An }}}$ & .0034 & $\begin{array}{r}-.0000002 \\
(-.002)\end{array}$ & $(-2.001) \mathrm{Am}$ & .19 & 5.36 aA \\
\hline 3 & $\frac{.19}{(1.73) \star \star}$ & - & - & $\begin{array}{r}-.00033 \\
(-.21)\end{array}$ & - & - & - & - & $(1.26)^{\circ}$ & $\frac{-.0038}{(-1.56)^{A}}$ & $(i .91)^{.00012}$ & -.00099 & $-\frac{.000001}{(-.01)}$ & $(-\vec{R}, 003) \wedge A$ & .18 & 4.74. \\
\hline 4 & $\begin{array}{l}.10 \\
(.99)\end{array}$ & -- & -- & - & $(-2.76)^{A \times A}$ & $\ldots$ & - & - & $(0 ; 0013)$ & $(-1.0039$ & $\frac{.00013}{(2.05)^{\mathrm{kA}}}$ & $\begin{array}{l}-.075 \\
(-.84)\end{array}$ & $\begin{array}{l}.00015 \\
(1.13)\end{array}$ & -.00008 & .23 & $6.62 \mathrm{kA}$ \\
\hline 5 & $\frac{.25}{(2.13) \mathrm{An}}$ & - & - & - & $\therefore$ & $(-2.44)^{-.28}$ & -.- & $\cdots$ & (1.62)* & $\frac{-.0046}{(-2.19)^{A k}}$ & $\frac{.00016}{(2.43) \star A \star A}$ & $\begin{array}{l}-.033 \\
(-.33)\end{array}$ & $\begin{array}{r}-.00002 \\
(-.28)\end{array}$ & $\frac{-.004}{(-2.35)^{A A A A}}$ & .27 & $i 8.00 * t$ \\
\hline 6 & $\frac{.21}{(1.72) A n}$ & --- & - & - & -- & - & $i^{0.1002}$ & - & $\begin{array}{c}.15 \\
(1.27)\end{array}$ & $\begin{array}{c}-.0049 \\
(-1.79)^{4 k}\end{array}$ & $\cdot(2.008)$ & $(.0025)$ & $\begin{array}{c}.0000001 \\
(.001)\end{array}$ & $\frac{-0042}{(-2.14) A A}$ & .23 & $6.19: 1$ \\
\hline , & $\frac{.19}{(1.70) \approx A}$ & - & - & --. & - & - & $\ldots$ & $-(-.0003$ & $(1.27)$ & $(-1.67)^{-.0042}$ & $\left(i^{0.0012}\right.$ & i. & $\begin{array}{l}.000002 \\
(.031)\end{array}$ & $\begin{array}{l}-.0035 \\
(-i .82) \mathrm{Am}\end{array}$ & .19 & $4.97 \times$ \\
\hline
\end{tabular}

HOTES: 1) SIGHA is the annuallized standard devtatton of asset roturns calculated from Gorton-Santomero (1989) subordinated debt option
pricing methodology then the on-bilance debt is augmented by

2) AOB, ACOAH, APART, ASLC, ACIC, ASWAP and AOBS reprosent seven

3) IEV, DIV, AGAP, ALOSS, POR and ASIZE represent IInanclal lever-

age diverslftcatlon lndex, toterest rate risk, credit rlsk,

dividend payout and logarititia of assets respectively;

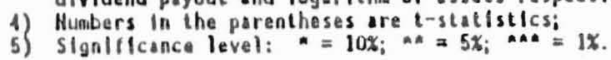

